\title{
Jazz na Slovensku v období fašizmu
}

\section{Jazz Music during the Fascist Regime in Slovakia}

Yvetta Kajanová / kajanova@fphil.uniba.sk

Department of Musicology, Faculty of Arts, Comenius University, Bratislava, SK

\begin{abstract}
This study presents new findings about jazz music in Slovakia at the time of World War II. Research has discovered that during the fascist Slovak State semi-professional orchestras consisting mainly of Romani and Jewish musicians also played jazz in small towns, where they were less conspicuous to the Nazis. Jazz ensembles and Romani bands substituted for the shortage of orchestras needed for live broadcasts. One special category was "military jazz". Divisions of Hlinka Youth also included jazz bands and, paradoxically, these were considered as part of youth education. The theatres in Zvolen, Nitra, and Prešov had jazz orchestras performing in their shows. The press of the time featured ensembles, such as the Hans Knauer Orchestra, the Perschitz Orchestra, and the František Prášil Orchestra, whose names have not been mentioned until now by any other theorists. Newspapers offered a rather "glorifying" and "optimistic" interpretation of jazz, which significantly contrasted with the offensive and racist attacks on the Czech "potápka" [duck/grebe] jazz subculture.
\end{abstract}

\section{Keywords}

Slovak State, swing, fascism, World War II, jazz, entertainment music 


\section{Slovenská republika vo vojnových rokoch}

V rozhlase dostali po vypuknutí vojny zákaz vysielat skladby amerických, anglických, francúzskych, sovietskych, českých a židovských skladatel'ov. ${ }^{1}$ Vysielala sa najmä nemecká hudba v percentuálnom zastúpení 50-66\%, 30\% mala slovenská tvorba. Nemecké smernice ministerstva propagandy ${ }^{2}$ určovali, čo je v jazze dobré a čo zlé. Rozhlas a tlač podliehali cenzúre na úrovni okresných úradov. Smernice a pokyny pre cenzúru vydávalo Prezídium ministerstva vnútra, uplatňovanie cenzúry zabezpečovali komisári a dôverníci vo všetkých inštitúciách. ${ }^{3} \mathrm{~V}$ rozhlase prebehli personálne zmeny, ktoré ospevoval časopis Slovák:

„Ked' zmizli individua, ktoré pod egidou centralizmu otravovali slovenských poslucháčov [...] črtali sa prvé náznaky úplne nacionálneho programu slovenského. “4

„Ideová výchova udávaná Vodcom"5 cenzurovala publikované články, repertoár, názvy a texty skladieb.

V slovenských mestách bola populárna najmä opereta, dominovali tangá, ale hrali sa aj valčíky, polky, čardášový fox, veselý fox, l’udový fox ako tance, kde sa miešala l’udová hudba s foxtrotom. Na vidieku sa pestovala l'udová hudba. Opereta bola starou formou zábavy v porovnaní s inými vel'komestami, kde sa šíril swing.

Na rozdiel od Protektorátu, kde hudobníkov mohli angažovat’ samotní majitelia kaviarne alebo zábavného podniku, na Slovensku museli všetci hudobníci prejst’ cez kvalifikačné skúšky Hudobnej komory, aby ich zaradili do kategórií. ${ }^{6}$ Hudobná komora vznikla 17.5.1939, vydávala nariadenia, podla ktorých židia ${ }^{7}$ a rómski hudobníci nemohli byt jej členmi. ${ }^{8}$ Napriek útočným a urážlivým nariadeniam v duchu nacistickej ideológie sa o rómskych hudobníkoch písalo v apríli 1940 pozitívne, akoby oficiálna kultúrna politika prezentovala niečo iné, než čo si bežná populácia myslela:

1 GÁLOVÁ, Jana. Hudobné vysielanie slovenského rozhlasu v období 2. svetovej vojny, Musicologica.eu, 12.5.2012, č. 1, 2012.

2 Smernice z novembra 1942, vydané Ríšskou hudobnou komorou v Berlíne, vyšli v českom Zpravodaji odborového sdruženi hudebniki̊ pro Čechy a Moravu, roč. XII, december, 1942, č. 12, s. 3. Český preklad vychádzal z berlínskeho časopisu Film-Kurier. KOURA, Petr. Swingaři a potápky v protektorátní noci. Praha: Academie, 2016, s. 640; KOTEK, Josef - HOŘEC, Jaromír. Kronika české synkopy 1939-1961, II. Půlstoleti českého jazzu a moderni populárni hudby v obrazech a svédectvi současniku․ Praha: Supraphon, 1990, s. 64.

3 Vládne nariadenie č. 177 Sb.z. zo septembra 1938 a nariadenie zo 17. septembra a vládna vyhláška z 23. 9. 1938 č. 183 Sb. z. BAKA, Igor. Politický systém a režim Slovenskej republiky v rokoch 1939-1940. Vojenský ústav, Bratislava: 2010, s. 17.

4 Budujme dobre svoj rozhlas! II. časṫ. Slovák, 19. 4. 1939, s. 3.

5 Slovák, 17. 3. 1939.

6 ZELENAY, Pavol - ŠOLTÝS, Ladislav. Hudba, tanec, pieseñ. Bratislava: HC, 2008, s. 102.

7 Regierungsverordnung Nr. 116/39 vom 17. Mai 1939 über die Grundung Musikkamer. Slovenský národný archív, sign. DP 84.

8 Protokoll Nr. 2 von der Kammerratsitzung am 28.IX.1939. Slovenský národný archív, sign. DP 84. 
„Hudobné nadanie u Cigánov je populárne a akosi dedičné z pokolenia na pokolenie. Hovori sa, že Cigáni sa rodia s huslickami. [...] Súdobý jazz znamená však v histórii cigánskych hudobnikov tažkú katastrofu lkajúcich strún cigánskych husli. Dnes, kedy táto horúcka pozvol'na upadáva, starý ,more Cigán - zaučuje malého ,purdé - cigánika - aby bol dobrým primášom. "9

Prenasledovanie židovských a rómskych hudobníkov bolo podložené zákonmi z rokov 1939-máj 1942. ${ }^{10} \mathrm{Na}$ začiatku ich uplatňovanie nebolo natol'ko silné, pretože v živom vysielaní rozhlasu účinkovali rómske kapely, ktoré suplovali nedostatok hudobníkov na Slovensku. V bratislavskom vysielaní to boli skupiny Jožka Horvátha, Jožka Pihíka, Lajoša Bittóa a v prešovskom rozhlase kapely Arpáda Dunu, Maxi Tatára a Františka Portelekyho. ${ }^{11}$ Po roku 1942, ked’ začali odchádzat transporty do koncentračných táborov zo Slovenska, sa hon na židovských a rómskych hudobníkov zostril.

V roku 1940 znela v nedelu rozhlase dvojhodinová relácia Jazz od 17:00 - 19:10, $\mathrm{v}$ pondelok hodinu doobeda a v noci od 22:15 Jazz a swing, ${ }^{12}$ do tanca hral v rozhlase Perschitzov jazz. ${ }^{13}$ „Vojenský jazz“ sa objavoval v poobedňajších „šturtkových rozhlasouých polhodinkách pre vojakov a civilné obyvatel’stvo“ v roku 1941, ktoré si „vel’mi obl’úbili a často vyslovovali v listoch svoje uznanie a želania."14 V rozhlase v júni 1941 vysielali poobede jazzovú hudbu z Prešova (17:00-19:15) a v nočných hodinách (21:00) „koncert vel’kého jazz-orchestra." 15

Cenzúra sa dala zneužit na osobné zámery. V rokoch 1939-41 hral na bratislavských plesoch a v rozhlase jazzový orchester Gejzu Šohára (data neznáme). V júni 1941 mal v rozhlasovom večernom vysielaní dva a pol hodinový program pod názvom Šohárov jazz, ${ }^{16}$ v septembri pol hodinový Šohárov jazz hrá do tanca. " 17 Potom nedostal povolenie od Hudobnej komory, kde mu bránil člen nemeckej sekcie Pepi Pur (data neznáme). Pur, ako leader „šraml orchestra,“ chcel odstránit konkurenta z bratislavského rozhlasu. Šohár potom zmenil meno na „Rahoš“ súbor (inverzia priezviska) a získal licenciu. V Rahošovom orchestri účinkovali hudobníci, oblúbení medzi poslucháčmi - Lucio Bosco, Vojtech Gabriel, Jozef Hlíza, Andrej Lieskovský, Pavol Polanský, Bohumil Slezák...

Prvé big bandy zostavili v Bratislave Teodor Šebo-Martinský (1911-80) pre potreby živého rozhlasového vysielania podla vzoru orchestra Jaroslava Ježka. ${ }^{18}$ Dvadsat členný swingový orchester Studio Jazz Ladislava Faixa (1908-67) vznikol ako štúdiový rozhlasový

9 F. K. Besednica. Kus orientu v srdci Európy. Slovák Pondelnik, roč. II, 29. 4. 1940, s. 5.

10 Dokumenty 1939-1949.

11 ZELENAY - ŠOLTÝS, ibid., s. 105.

12 Rozhlas. Slovák, roč. XXII, 7. 4. 1940, č., s. 13.

13 Rozhlas. Slovák, roč. XXII, 11. 9. 1940, č. 216, s. 9, Gardista, roč. II, č. 46, 5. 11. 1940, s. 7. Tu uvedené ako Preschitzov jazz.

14 Štvrtkové rozhlasové polhodinky. Gardista, roč. III, č. 22, 28. 1. 1941, s. 5.

15 Rozhlas. Gardista, roč. III, č. 140, 22. 6. 1941, s. 13.

16 Rozhlas. Gardista, roč. III, č. 133, 14. 6. 1941, s. 7.

17 Rozhlas. Slovák, roč. XXIII, č. 214, 17. 9. 1941, s. 6.

18 MATZNER, Antonín - POLEDŇÁK, Ivan - WASSERBERGER, Igor a kol. Encyklopedie jazzu a moderni populárni hudby I. Praha: Supraphon, 1983, s. 188. 
orchester (1939-41). Jeho členmi boli klaviristi Michal Karin-Knechtsberger (1908-88), Ladislav Holoubek (1913-94), huslista Vojtech Gabriel (1914-81). Studio Jazz Faix účinkoval aj na „I. jazzovej revue... vo vel'kej sieni Tatra-hotela v Bratislave“. ${ }^{19}$ Súčastou koncertu boli aj čísla komornej klasickej hudby. Účinkovala tu aj prvá ženská interpretka foxtrotov, populárnej hudby, ale aj klasiky, Magdalena Schwingerová, tanečníci stepu z tanečnej školy E. Fuchsovej-Lehotskej (mamy speváka pop music Janka Lehotského, *1947).

Ladislav Faix, ako redaktor pražského rozhlasu, čítal nariadenie o mobilizácii československej armády (23. 9. 1938), bol zatknutý a leadrom Studio Jazz sa stal Janko Matuška. V roku 1941 sa objavila správa, že o 21:15 bude rozhlas vysielat’ „tanečnú hudbu (studio-jazz diriguje Lad. Faix), " ${ }^{20}$ z čoho usudzujeme, že cenzúra začala do praxe nabiehat až po roku 1941, pretože meno Faix cez cenzúru prešlo. Aj Wasserberger udáva, že politické prenasledovanie Faixa začalo až v roku 1941. ${ }^{21}$ Ešte v roku 1940 hrával „bratislavský populárny 14-členný Studio-jazz“ Ladislava Faixa v kúpel’nej dvorane v Grand-hoteli v Trenčianskych Tepliciach. ${ }^{22}$ Orchester v roku 1942 zanikol a hudobníci sa stali členmi orchestra Ferdinanda Zischku (3 sax., 2 tp., trb, rytmika). Spomenutí leadri orchestrov sa uplatňovali aj ako skladatelia, komponovali v duchu vel'koorchestrálneho swingu a od roku 1944 začali používat tzv. block chords (úzku harmóniu, pridávanie sexty ku kvintakordom a pod.) podla vzoru orchestra Glenna Millera. ${ }^{23}$

\section{Dobové názory na jazz}

Správy o jazze neboli na stránkach dobovej tlače v prvej Slovenskom republike také útočné ako v Protektoráte Čechy a Morava. Po zhoršení situácie v zásobovaní a postupnom zavádzaní prídelového systému (1941, v Protektoráte bol prídelový systém zavedený okamžite) sa objavujú rasistické hlasy proti jazzu.

„Je pravda, slovenská l’udová pieseñ dostala konkurenciu v takzvanej modernej ,hudbe' [...] a ohrozuje l'udovú pieseň. Už aj dedinski mládenci a dievčatá nachytávajú sa na tento sladkastý lep a kazia si chut', takže spievajú miesto čistých a lahodných zvukov slovenskej muziky kalnú gebuzinu medzinárodných jazzových foxtrotov a táng. ${ }^{24}$

Jozef Hlavatý (J. H.) publikoval svoje subjektívne názory (1942) viackrát:

19 Drobné kultúrne zvesti. Gardista, roč. III, č. 22, 1941, s. 6.

20 Rozhlas. Gardista, roč. III, č. 135, 17. 6. 1941, s. 6.

21 MATZNER, Antonín - POLEDŇÁK, Ivan - WASSERBERGER, Igor a kol. III., 1990, s. 129; 1983 , s. 188.

22 tr. Večer klasických valčíkov a pochodov v Trenčianskych Tepliciach. Slovák, XXII, č. 169, 20. 7. 1940, s. 7.

23 ZELENAY - ŠOLTÝS, 2008, s. 117.

24 J. H. Otvorme poklady našej l’udovej piesne - Na týždeň slovenskej hudby - Konkurencia šlágrov, šansónov a kupletov. Slovák, roč. 23, č. 52, 2. 3. 1941, s. 3, 7. 
„A keď̌e jazz vedome podriadil melódiu rytmu, stal sa primitívnym prejavom bezduchého a exaltovaného, skoro kŕčovitého pohybu l'udského, moderného to vitovho tanca [...] v liečébných ústavoch. Tam pacient hýbe svojimi údmi podla rytmu stroja, tu, v tanci, na jazzovú hudbu pohybuje sa telo, ako by ho stroje mykali. [...] Ale jazz a všetky podobné akustické atrakcie sprotivia sa nám bezpečne až potom, ked' sa prevali vredovitý nános a moderná hudba vyjde čistá a vítazná zo svojho očisteného kvasenia. ${ }^{\text {"25 }}$

Takéto názory sa zhodovali s nacistickou ideológiou, podla ktorej americký jazz bol ,neárijský produkt nepriatel'ských plutokratov, negrov a židobol’ševikov. ${ }^{26}$

Podla smerníc Ríšskej hudobnej komory z novembra 1942 (Berlín) sa riadila aj Hudobná komora na Slovensku. Napriek tomu sa v roku 1943 objavuje článok, v ktorom autor nadšene reaguje na jazz. Spomína na obdobie pred vojnou, ked' chodili v noci tancovat do tanečných sál. Nočné podniky boli zatvorené a platil už zákaz tancovania. Step, foxtrot a swing pokladá za modernú hudbu:

„Zabúdam však neustále zdôrazňovat' to hlavné, čo atmosféru naplña, bez čoho by bolo v každom podzemnom či nadzemnom lokáli prázdno - jazz. Dnes je prežitkom valčí a tobôž čardáš a všetky tance $v$ retrospektíve až po rokokové štvorylky a ručnićkové. “ 27

Podla Úradnej vyhlášky z 15. októbra 1938, prevádzka bola obmedzená do 21. hodiny. Fungovali však výnimky, podla ktorých sa objavovali denne varietné programy s vel'kým jazzovým orchestrom v Bratislave od 22. hod v kaviarni Muzeum, ${ }^{28}$ v Záhrade umelcov od 19.-22.00 hod. ${ }^{29}$ Spotreba mäsa v reštauráciách a hostincoch bola obmedzená na jar 1941). Ak porovnáme 30. roky v Bratislave, kde hrávali v záhrade Krym denne 3 kapely - popoludní cigánska kapela Bélu Pita, po ňom železničiarska dychovka a večer renomované tanečné kapely s dobrým menom, vidíme podstatnú zmenu v hudobnom živote.

V máji 1944, ked' vrcholila situácia na fronte, sa objavili v novinách neškodné úvahy o rozdielnosti vážnej hudby, zábavnej i jazzovej hudby:

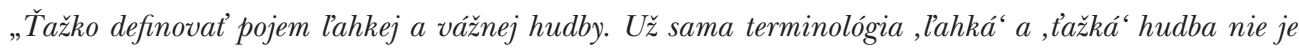
priam výstižná. Ved' hudba je iba jedna. [...] Medzi vážnou a l’ahkou hudbou je dnes vel'ká priepast. Nejde vlastne o boj proti hodnotnej l'ahkej hudbe, ako skôr o získanie záujmu širokých vrstiev pre cennú, vážnu hudbu. “ 30

O jazze sa tu píše ako o zábavnej hudbe, ktorá je synonymom populárnej hudby a počúva sa denne.

25 HLAVATÝ, Jozef. Čo pišu inde. O stažnostiach na lahkú hudbu. Slovák, roč. XXIV, č. 71, 27. 3. 1942, s. 7.

26 BÁLINTOVÁ, LENKA. Džez, zakázaná hudba. Historická revue, 2000, roč. XI, č. 6, s. 29.

27 J.V. Beethoven a jazz. Národnie noviny, roč. 74, č. 39, 1943, s. 1, 3.

28 Slovák, XXIV., 29. 8. 1942, č. 196, s. 6.

29 Gardista, IV., 20. 6. 1942, č. 138, s. 8.

30 Slovo o lahkej hudbe a Gregoriánskom chorále. Gardista, roč. VI, č. 115, 21. 5. 1944, s. 16. 
„[...] s jazzom sa stále stretávame, denne ho počúvame. [...] Hlavnou črtou jazzu je dráždivý, ostro zdôrazňovaný rytmický prvok a použitie synkop [...]. Jazzová hudba do istej miery ovplyvňuje aj hudbu vážnu. Jej prvky nachádzame v moderných suitách, ba i v symfóniách [...] (Stravinský a Hindemith)."31

Tieto úvahy na stránkach tlače boli luxusom a únikom v období fašizmu, akoby autori nevedeli o skutočných udalostiach. V druhej polovici vojny postihol takmer všetky kapely v Protektoráte povinný nástup na nútené práce, čo slovenskí hudobníci nemuseli. ${ }^{32}$

\section{Hudobníci}

Zo študentov bol zostavený Orchester Združenia („Sdruženia,“ „Sdruženi““) vysokoškolského študentstva pod vedením Jána Ondruša. Orchester vznikol v roku 1942, aj ked’ sa dobové pramene líšia. ${ }^{33}$ V roku 1943 účinkovali v bratislavskej Redute (6. 3. 1943), na viacerých miestach na Slovensku, na reprezentačnom večierku slovenských vysokoškolákov vo Viedni, vo vojenských v posádkach, v nemocniciach a pre vojakov vo výcvikových strediskách. Vo dvorane bratislavského hotela Tatra (7. 3. 1943) sa konal ich 'Monstrekoncert.' Hoci Zelenay ${ }^{34}$ hovorí o „Monstrekoncerte“ ako počas turné R. A. Dvorského ${ }^{35}$ v roku 1940, ktoré sa zmenili na národný protest Čechov proti fašizmu, recenzia Orchestra Združenia vysokoškolského študentstva má skôr charakter podpory a oslavy existencie slovenských telies.

Pred vystúpením sa objavila správa:

„Bohatý program kabaretu, ktorý si ziskal aj náročné viedenské publikum, je zárukou, že sobotřaǰ̌i večer prežijete v prijemnom ovzduši, za zvukov vel'kého jazz-orchestra. O dobré vtipy sa postará desat' konferanciérov. Zlatým klincom programu je pohostinné vystúpenie ,kocúrkovských študentov', ktori sa u nás zastavili na svojej ceste za slávou. “36

Po vystúpení sa objavila v novinách recenzia:

„Prvé vystúpenie hudobného oddelenia Združenia vysokoškolského študentstva pred bratislavskou verejnostou stretlo sa s úspechom. Program kabaretu, zostavený starostlivo a účelne, vynikol obsahovou pestrostou a vyrovnal sa v každom smere programom podnikov tohto druhu. Nezabudlo sa pri ňom na nič,

\footnotetext{
31 Ibid.

32 SChVARC, Michal - HALLON, Ludovít - MIČKO, Peter. Pracovali v Tretej riši. Bratislava: Veda, 2015, s. 15,33 .

33 ZELENAY - ŠOLTÝS, uvádza rok 1942, s. 120, další 1940, In: MATZNER, Antonín - POLEDŇÁK, Ivan - WASSERBERGER, Igor a kol., 1990, s. 394.

34 ZELENAY - ŠOLTÝS, 2008, s. 120.

35 O.K. Třistakrát dvojka z mrav: vinen R. A. Dvorský [Three hundred times, bad marks for conduct]. Kinorevue, VI, no. 44 (1940), 358-360, in: Kotek, 1990, s. 43.

36 -š.: Chcete sa príjemne zabavit a zasmiat?? Slovák, roč. XXV, č. 52, 4. 3. 1943, s. 5.
} 
aby obecenstvo prijalo program radostne so smiechom a spokojnostou. Kabaret vychádzal zo štyroch programových základov: tanca, hudby, spevu a humoru. Z tanečných vložiek vynikol chrámový tanec F. Jaurega a čardáš v presvedčivom predvedeni slečny $V$. Mihalovej. O úspech v spevných výstupoch sa rozdelilo vokálne trio v zloženi: Karasová, Kašliková a Žáková. (vokálne trio Včielky, pozn. autora) Do programu harmonicky zapadali vložky lahkej hudby dvadsat’pätčlenného jazz-orchestra, ktorý pod taktovkou Jána Ondruša podal hudobno pôsobivý výkon a získal vel'ké sympatie bratislavského obecenstva. Prestávkové medzery účinne vyplňovali konferenciéri: A. Tkáč a D. Hapala, ktorých zdravý humor rozveseloval celé hladisko." 37

Ked' sa vrátil z Nemecka Ady Helman (1943), bol dosadený za dirigenta orchestra, pretože napodoboval nemecké revuálne orchestre a Ondruš, ako Slovák, sa stal jeho zástupcom. O Orchestri Združenia vysokoškolského študentstva sa písalo:

„[...] tridsat’clenná kapela najväčšieho jazz orchestru na Slovensku, vedená kapelnikom A. Helmannom, spustila mohutné akordy ouvertúry, ktorých pôvodcom je vysokoškolák Slezák. [...] Z hudobných a speváckych čísel treba zvlášt' vyzdvihnút', pieseň o bielej ruži', ktorú za vlastného doprevádzania na gitare zaspievala slečna Golovková. Velkého úspechu dosiahol swing akademika Jazova, ktorý zaspieval J. Tesák. [...] Kabaretný program spestrilo i zmenené rozhlasové spevácke kvarteto, Čmelári (Čmeliaci, pozn. autorky) a gitarové duo Paveleka a Ned'ved'a. Po zatváracom prejave program zakončil jazzový orchester SVŠ (Sdruženie vysokoškolského študentstva, pozn.autorky). Frontovi raneni vojaci každé čislo programu odmenili srdečným úprimným potleskom. "38

Orchester predviedol „vel'ký kabaret“ aj vo Zvolene (12. júna) „v divadelnej sieni Grandu pod protektorátom Miestnej organizácie HSLS“:

„V̌̌etci účinkujúci podali pekné výkony, no najlepšie sa páčil velký jazz-orchester. Priestranná divadelná sieň bola nabitá vd’ǎným obecenstvom zo Zvolena a okolia." "39

Ked' sa ukázalo, že študentský orchester je schopný profesionálne hrat', niektorí jeho členovia vytvorili malý orchester pod názvom Pracovný sbor národnej obrany Ministerstva národnej obrany, ktorý dirigoval Zdenko Hron-Mikula (1916-2012). ${ }^{40}$ Tento orchester Pracovného sboru sa využíval najmä na vojenské príležitosti, vystupoval špeciálne pre vojakov na fronte.

V orchestri Sdružení vysokoškolského študentstva začínal aj Pavol Polanský (1925-2010) so židovským pôvodom. Vyhol sa transportu do koncentračného tábora v roku 1944, ked' sa za neho zaručil vplyvný prešporský Nemec, ktorý mal rád jazz ${ }^{41}$. V menšom obsadení sa Sdruženie vysokoškolského študentstva počas prázdnin (9. 7. 1943) pod hlavičkou Fron-

37 Úspech kabaretného vystúpenia SVŠ. Slovák, roč. XXV, č. 57, 10. 3. 1943, s. 6.

38 K. KLINČEK. Vysokoškoláci medzi ranenými frontovými vojakmi. Slovák, roč. XXV, č. 114, 19. 5. 1943, s. 6 .

39 (ah): Velký kabaret SVŠ vo Zvolene. Slovák, roč. XXV, č. 138, 18. 6. 1943, s. 5.

40 (-r-), 'Hudobné nešpory ranených vojakov'. Slovák, roč. XXV, č. 111, 15. 5. 1943, s. 2.

41 ‘Čo Slovensko chcelo, to má...' . týždeň, 2008. 
tového divadla Sdružení vysokoškolského študentstva pod vedením npor. kap. Zdenka Mikulu dostal na zájazd na Krym, odkial’ po 6 týždňoch po „mohutnej ofenzive Červenej armády [...] utekali na nákladných autách..."42 Orchester sa rozpadol v roku 1944, ale tesne pred SNP sa objavila správa, že v redukovanom obsadení účinkovali v Banskej Bystrici:

„Na pozvanie akcie Radost' z práce pri SPP zavita v utorok 22. t. m. do Banskej Bystrice kabaretný súbor bratislavských vysokoškolákov Kaktus pod Bambusom, kde sa večer o 8. hod. vo vel'kej dvorane Národného domu“43 predstavili v programe s jazzom a vystúpila aj Baletná skupina školy E. Fuchsovej-Lehotskej.

Podla správ z marca 1943 mal orchester Sdruženia vysokoškolských študentov 25 členov, ${ }^{44}$ pri vystúpeniach vo Viedni 30 členov, Zelenay ${ }^{45}$ udáva, že počet bol premenlivý až do 47 členov.

Ked' začali transporty Židov a Rómov zo Slovenska do koncentračných táborov (marec 1942), ukázala sa absencia hudobníkov na Slovensku. Ked’že Slovenský rozhlas musel vyrábat programy pre celé Slovensko bez kontaktu na české stanice, bol založený Malý rozhlasový orchester (1.augusta 1942). Vzniklo tu 14 platených miest, avšak niektorí hudobníci museli hrat na viacerých nástrojoch ako Vojtech Gabriel, Jaroslav Vycpálek, Ferdinand Zischka, pretože bol nedostatok hudobníkov. Orchester dirigoval Anton Matschek. ${ }^{46}$ Hrával v ňom aj taliansky klarinetista Lucio Bosco, ktorý sprostredkoval bratislavským jazzmenom gypsy jazz ${ }^{47}$ a swing v malých combách. Spomeňme d’alšie dôvody nedostatku hudobníkov - slovenskí hudobníci Juraj Berczeller (1914, Šahy-2008, Sydney) so židovským pôvodom a Gejza Toperczer (1916, Košice-1984, Košice) pôsobili v Budapešti, ked’že Šahy a Košice, ako ich rodné mestá, sa pričlenili k Mad’arsku. Klavirista Karol Elbert so židovským pôvodom sa z Košíc, ktoré patrili Mad’arsku, presunul do Dancing Felix podniku v Žiline. Pôsobil v Banskej Bystrici v triu s Gejza Russó a Vilém Kollis. Neskôr s Jancsim Illésom pod názvom Illés jazz a s Lajosom Tököly v hoteli v Bánovciach nad Bebravou sa mu darilo skrývat’ sa pred fašistami. Pri komentovaní športového turnaja tenistu Mariana Filu v Žiline, ktorý prehral, novinár v eseji vtipne píše:

„Predvidavé vedenie istého žilinského hotelu angažovalo ako hudbu, Illés jazz‘ ako by bolo už vopred tušilo, že Illés vyhrá nad ,Fillom‘. Ináč vraj mali hudobníci pripravené pre každý prípad aj nápis, Fillo jazz, “"48 ak by bol vyhral.

42 ZELENAY - ŠOLTÝS, s. 122.

43 Oš: Kabaretný súbor vysokoškolákov do B. Bystrice. Gardista, roč. VI, č. 185, 17. 8. 1944, s. 5.

44 Úspech kabaretného vystúpenia SVŠ. Slovák, roč. XXV, č. 57, 10. 3. 1943, s. 6.

45 ZELENAY - ŠOLTÝS, tamtiež.

46 ZELENAY - ŠOLTÝS, 2008, s. 124.

47 MAZZOLETTI, Adriano: Il jazz in Italia. Volume secondo dallo swing agli anni sessanta. Torino: EDT, 2010, s. 87; MAZZOLETTI, Adriano: Il jazz in Italia. Dalle origini alle grandi orchestre. Torino: EDT, 2004, s. 371, 390.

48 Pardon, na okamih... Slovák, roč. XXIII, č. 162, 17. 7. 1941, s. 10. 
V pieštanských kúpeloch hostovali jazzové kapely od otvorenia sezóny v roku 1943, kde „v Bacchus grile“ hrala „každý deň od 8. hod. večer do zatváracej hodiny v noci dobrý jazz Tökölyho..." ${ }^{49}$ Elberta (1911-1997) zatkli a odviezli do Osvienčimu v septembri 1944, ${ }^{50}$ avšak hrôzy koncentračného tábora prežil.

\section{Jazzové orchestre v Bratislave}

Swingové orchestre účinkovali počas vojny pri rôznych podujatiach, ktoré organizovali súkromné organizácie ako napríklad Zábavný výbor Slovenskej odborovej jednoty súkromných úradníkov, ${ }^{51}$ Miestne velitel’stvo Hlinkovej gardy v Bratislave ${ }^{52}$. Podla dobových inzerátov mali svoje vlastné jazzové orchestre.

V Bratislave v reštaurácii u Detvana v marci 1940 denne hrávala jazzová hudba cigánskeho kapelníka Berkiho. ${ }^{53}$ Na majálese v bratislavskej Rači v Katolíckom kultúrnom dome Andreja Hlinku hrali jazzové orchestre ${ }^{54}$. Športový deň v Karlovej Vsi (september 1940) končil tanečnou zábavou, ${ }^{55}$ na ktorej účinkovali jazzové kapely. Na I. národnom plese v Bratislave v decembri 1940 vystupoval Studio Jazz Ladislava Faixa a „vel’ká cigánska kapela Jožka Pihika, ktorá nacvičuje osobitné zábavno-hudobné č́sla. " ${ }^{56}$ Jazz sa hrával v bratislavskej kaviarni Park (zima 1941). ${ }^{57}$ Ked’ sa vojnová situácia pre civilistov zhoršovala, Klub slovenských turistov a lyžiarov organizoval športové rekreačné tábory na chate pod Rysmi, kde znel aj jazz (leto 1941), ale dôležitejšie bolo, že účastníci mali k dispozícii „provotriednu a výdatnú stravu 3 razy denne ... člnkovanie, volejbal, plávanie, lahká atletika, vychádzky, exkurzia do okolia, lukostrel'ba, táborové ohne, programové večierky, originál jazz, čitáreñ, knižnica. "58

V dobovej tlači sa dočítame mená kapelníkov Hans Knauer, Perschitz ${ }^{59} /$ Preschitz $^{60}$, doteraz nespomínaných v dostupnej literatúre.$^{61}$ Rozhlasový jazzový orchester Hansa Knauera v auguste 1941 denne účinkoval v spoločenskom dome Múzeum, ${ }^{62}$ na Týždni Dunajského

49 Hlavná sezóna v Pieštanoch otvorená. Slovák, roč. XXV, č. 108, 12. 5. 1943, s. 5.

50 SCHINDLER, ibid., s. 171-174.

51 Zábavy - Večierky. Slovák, roč. XXII, č. 100, 27. 4. 1940, s. 7.

52 Zábavy. Slovák, roč. XXII, č. 152, 29. 6. 1940, s. 14.

53 Slovák, XXII, č. 67, 20. 3. 1940, s. 6.

54 Kat. Kultúrny dom Andreja Hlinku. Slovák, roč. XXII, č. 101, 28. 4. 1940, s. 16.

55 Športový deň v Karlovej Vsi. Slovák, roč. XXII, č. 223, 19. 9. 1940, s. 8.

56 Predpredaj vstupeniek na I. národný ples v Bratislave. Gardista, roč. II, č. 90, 29. 12. 1940, s. 8.

57 Slovák, roč. XXIII, č. 279, 4. 12. 1941, s. 8.

58 (sb.): Na rekreáciu do našich hôr s AOKSTL (Akademický odbor Klub slovenských turistov a lyžiarov). Slovák, roč. XXIII, č. 155, 9. 7. 1941, s. 8.

59 Rozhlas. Slovák, roč. XXII, č. 216, 11. 9. 1940, s. 9.

60 Gardista, roč. II, č. 46, 5. 11. 1940, s. 7.

61 MATZNER et al., 1990; ZELENAY - ŠOLTÝS, 2008.

62 Slovák, roč. XXIII, č. 197, 28. 8. 1941, s. 6, Podla správy Knauer tu účinkoval aj v novembri 1941 o 22:00, Slovák, XXIII, č. 262, 13. 11. 1941, s. 2. 
veltrhu (september 1941), kde ho predstavovali ako reprezentanta „vel'komestského jazzu. “63 $\mathrm{Na}$ „týždeni Dunajského vel'trhu“ zneli aj „náladové hudby cigánskych kapiel Farkaša, Cibul’ku, Bittóva i ostatných primášov. "64

Ďalší, málo spomínaný ${ }^{65}$ jazový kapelník bol Emerich (Imrich) Maroš. V októbri 1941 otváral sezónu v najslávnejšom bratislavskom podniku Etablissement Astoria. ${ }^{66}$

V súvislosti s jazzom sa spomína aj pozvanie na zábavu slovenských akademičiek pod "protektorátom Boženy Tukovej "67, kde hostia môžu príst̉ oblečení v krojoch. Stojí za zmienku, že podobná situácia sa objavila aj v Protektoráte, kde v dámskom jazzovom orchestri dánskej saxofonistky Karen Ostrá, účinkovali hudobníčky oblečené v kroji. ${ }^{68}$ Do protikladu sa tu dostáva národný charakter hudby s kozmopolitným zameraním jazzu.

Swingové orchestre účinkovali aj koncertne s umeleckým programom na počúvanie vo vel'kej sieni v Redute v Bratislave - Orchester Odeon (vydavatel'stvo) dirigoval Štefan Mózsi v novembri $1941 .^{69}$

Vo vel'kej sieni v Redute sa uskutočnila Silvestrovská revue (1943), kde účinkovali František Dibarbora, Karol Zacharom, speváci Mutňanská, Krištofom Veselým, jazz-orchester Slovenského rozhlasu a baletná skupina Ely Fuchsovej-Lehotskej. ${ }^{70}$

\section{Jazz a mládež}

Podla krátkych správ vieme, že vo vojnovom období boli pre jazz nadšení najmä študenti. Pri organizovaní „veselého večierku za vel'kej účasti obecenstva Rodičovského združenie a Kraskovho vzdelávacieho krúžku pri II. slovenskom štát. gymnáziu" ${ }^{71} \mathrm{v}$ Bratislave znel jazz študentského orchestra. Jazz bol aj súčastou výchovy mládeže, ktorá sa grupovala v Hlinkovej mládeži v Ilave. Ked' skladali sl’ub vernosti miestnemu vodcovi Ladislavovi Verešovi, mali „35 víčat, 32 orlov a 30 junákov“ (delenie organizácie podla veku, pozn. autorky) a „aj svoju hudbu, nazvanú ,Jazz Junák““.72

Vlastný jazzový orchester mala aj „Remeselnícka Hlinkova mládež a učñovská besiedka v Nitre,“ kde sa uvádza, že by bolo „účelné, keby sa utvoril tovarišský spolok ako pokračovanie učňovskej besiedky. Takto by nevyšla na zmar práca, ktorá sa vložila do výchovy mládeže cez učňovské roky. "73 Jazz hrali aj študenti v Ružomberku (máj 1945):

63 (r.c.): Týždeň spoznávania sa. Slovák, roč. XXIII, 5. 9. 1941, č. 204, s. 6.

64 Ibid.

65 Emerich (Imrich) Maroš, Zelenay - Šoltýs, ibid., s. 103, 104, 108, 117, 133.

66 Slovák, roč. XXIII, č. 224, 28. 9. 1941, s. 6.

67 Božena Tuková bola manželkou Vojtecha Tuka (1880-1946), predsedu vlády Slovenskej republiky. Slovák, roč. XXIII, č. 259, 9. 11. 1941, s. 10.

68 Seveřanka okouzlená českým folklórem, Telegraf, 15. 12. 1940, Kotek, ibid., 1990, s. 40.

69 -us-: Slovák, roč. XXIII, č. 261, 12. 11. 1941, s. 6.

70 Rozlúčka so starým rokom. Slovák, roč. XXV, č. 299, 31. 12. 1943, s. 5.

71 J. -1́k. Večierok bratislavských stredoškolákov. Slovák, roč. XXIII, č. 292, 20. 12. 1941, s. 7.

72 TSHM. Hlinkova mládež. Slovák, roč. XXII, č. 124, 29. 5. 1940, s. 5.

73 Zvesti. O založenie spolku pre tovarišov v Nitre. Gardista, roč. III, č. 287, 16. 12. 1941, s. 5. 
„Ružomberski vysokoškoláci, začleneni do pomocných služieb SČK (Sväz červeného kríža, pozn. autorky) pri evakuačných komisiách v Ružomberku, usporiadali zábavný kabaret. Na programe boli divadelné výstupy, spevné a hudobné čísla a jazz-orchester. Zisk $13.000 \mathrm{Ks}$ venovali Červenému križu. "74

Jazz sa rozvíjal dokonca i v malých mestách. Športový klub Tatra v Kysáči organizoval vo februári 1940 maškarný ples, kde účinkovala jazzová kapela z Nového Sadu zo Srbska. ${ }^{75}$ Ján Murgoň hladal jazzové trio pre účinkovanie v kaviarni v Levoči ${ }^{76} \mathrm{v}$ januári 1940, „vel'ký jazz-orchester pod vedením kapelnika Ahrháma“ 77 začal koncertovat' v hoteli Slovan v Turč. Sv. Martine v lete 1941. V prešovskom Solivare „účinkoval prvý raz aj The Jam Jazz, ktorý sa môže vypracovat’ časom na dobrý jazz."78 V apríli 1944 účinkoval 11-členný jazz orchester z Dubnice v Trenčianskej Teplej a pripravovali „d’alši zájazd do Trenčina."79

\section{Vojenský jazz}

Ked’že záznamy z koncertov rozhlasového vysielania sa nezachovali, nevieme presne, čo sa rozumelo pod názvom „vojenský jazz.“" 80 Spávy o vojenskom jazze sa objavili v Novom meste nad Váhom, kde pre vojakov, ktorí sa pristahovali do mesta, usporiadali čajový večierok. Účinkoval na ňom „prvotriedny jazz-orchester, za dirigovania JUC. R. Hrebenára."81 Podla dobových správ sa domnievame, že „vojenský jazz“ bolo len iné označenie pre swingový orchester, ktorého členovia hrali pod záštitou Ministerstva národnej obrany, ale do repertoáru pridávali aj vlastenecké a pochodové skladby:

„Vojenská propaganda Ministerstva národnej obrany usporiada vo šturtok v miestnosti kina Uránia (v Bratislave, pozn. autorky) vel’ký zábavný večierok. Na programe bol kabaret, ktorý navštívilo početné obecenstvo a tak dokumentovalo pochopenie pre podnik našej armády. Medzi divákmi boli aj raneni vojaci. Zábavný večierok mal velký úspech, o čo sa predovšetkým pričinili herci-komici ND Zachar, Dibarbora, Jariabek a Zvarik. Velmi prijemným prekvapením bol skvelý vojenský jazz pod taktovkou npor. Mikulu. Aj ostatni účinkujúci: F. K. Veselý, M. Mutñanská, A. Flögl, M. Vlková, M. Černická, L. Jurícková, M. Beran a Vycpálek sa tiež značne pričinili o pobavenie prítomných vojakov. "82

Gardista, roč. VII, č. 8, 11. 1. 1945, s. 3.

75 „L-en“. Národná Jednota, roč. XXI, č. 5, 3. 2. 1940.

76 Slovák, roč. XXII, č. 4, 5. 1. 1940, s. 10.

77 Slovák, roč. XXIII, č. 185, 13. 8. 1941, s. 8.

78 (ok). Kultúrny večierok v Solivare. Slovák, roč. XXII, č. 205, 29. 8. 1940, s. 9.

79 Jazz dubnických podnikov v Trenč. Teplej. Gardista, roč. VI, č. 85, 14. 4. 1944, s. 8.

80 Štvrtkové rozhlasové polhodinky. Gardista, roč. III, č. 22, 28. 1. 1941, s. 5.

81 Čajový večierok novomestskej Živeny. Slovák, roč. XXII, č. 94, 20. 4. 1940, s. 6.

82 Kaleidoskop mal úspech. Gardista, roč. V, č. 145, 26. 6. 1943, s. 5. 
Názor o charaktere vojenského jazzu potvrdzuje i správa z decembra 1943, kde „aspiranti vojenskej posádky v Trebišove" usporiadali Silvestrovský večierok, na ktorom účinkoval „vojenský jazz-orchester z Prešova... vo všetkých miestnostiach trebišovského cukrovaru. "83

\section{Jazz a divadlo}

Jazzové orchestre boli súčastou revuálnych programov s konferansom, divadelnými scénkami, gagov komikov, operetnými číslami a cigánskymi skupinami, ktoré hrávali jazz v modifikovanej hybridnej podobe čardášových foxov. Pri divadlenom predstavení IV. Úseku Hlinkových dopravných gardistov vo Zvolene „na tanečnej zábave účinkovala vel’mi dobrá hudba jazz-orchestru HDG (Hlinkoví dopravní gardisti, pozn. autorky)“. ${ }^{84}$

Vo vojnových časoch boli vystúpenia na vidieku vzácnostou. V lete 1944 sa divadelný súbor z Nitry predstavil pre vel’ký záujem obecenstva v Urmíne trikrát:

„[...] zábavný súbor OVHM v Nitre [...] sa predstavil urminskemu obecenstvu veselým kabaretom ,Celý svet je na ruby. ' Program sa opakoval tri razy... na vkusne upravenom, hoc i malom javisku, kde sedel jazz-orchester ,Hviezda', vedený taktovkou M. Š. Lukáča [...] Nesmieme zabudnút tiež na majstra J. Tolnayho, ktorý predniesol na husliach urminskemu obecenstvu krásne skladby a bol odmenený dlhotrvajúcim potleskom prítomných. "85

Novozaložené „Slovenské divadlo v Prešove“86 (Košické divadlo zaniklo po pričlenení Košíc do Mad’arska) uviedlo premiéru „veselohry M. Rössnera „Karol III. a Anna I. “, na ktorú „hudbu zložil a jazz-orchester dirigoval František Prášil. “87 Meno Prášil sa tu objavuje po prvý raz spolu s jazzovým orchestrom v Prešove.

\section{Po oslobodení}

Hned' po oslobodení hostoval v Bratislave na pozvanie Sväzu slovenskej mládeže Orchester Gustava Broma. ${ }^{88}$ Rozbiehali sa rómski hudobníci - dobový citát nie je pejoratívny, naopak autor ich nazýva „bratislauski cigáni“, ale vzápätí použíje aj slovo „hudobníci“:

„Pod protektorátom Zväzu protifašistických väzňov a ilegálnych pracovnikov usporiadajú dňa 1. júla t. r. o pol 11. hodine vo velkej sieni Reduty bratislavski cigánski hudobníci Monstre Koncert. Účinkujú

83 Silvestrovský večierok v prospech frontových invalidov v Trebišove. Slovák, roč. XXV, č. 297, 29. 12. 1943, s. 5.

84 Zvolenská HDG - kultúrne činná. Gardista, roč. II, č. 24, 14. 6. 1940, s. 11.

85 (čan). Kabaretný súbor z Nitry v Urmíne. Slovák, roč. XXVI, č. 170, 30. 7. 1944, s. 6.

86 (h). Z repertoáru Slovenského divadla v Prešove. Slovák, roč. XXVI, č. 59, 11. 3. 1944, s. 4.

87 Ibid.

88 - Koncert 'v melódii a v rytme' v Bratislave. Pravda, č. 118, 17. 7. 1945, s. 4. 
70-členná cigánska kapela, 20-členný jazz orchester, členovia ND a sólisti. [...] Bratislavskí cigáni, hudobnici nastupujú dnes do intenzínej, radostnej práce. [...] naši bratislavski hudobníci pripravujú medziiným i koncert pre Červenú armádu v budúcom týždni, ako aj koncert pre robotnikov bratislavských továrni [...] na platforme ludovej demokracie [...]." ${ }^{89}$

Pár dní po vojne sa objavila správa, že Socialistický sväz mládeže chcel sústredit študentov do jedného jazzového ensemblu: „Hudobnici - študenti, ktori chcú hrat’ vo vysokoškolskom jazz-orchestri, nech odovzdajú svoje adresy v sekretariáte SSM vysokoškolský odbor, Bratislava, Zelená č. 1/II. " ${ }^{90}$ Avšak, blí̌̌il sa nový komunistický diktát, ktorý preferoval sovietsku hudbu a hudbu hodnú socialistického človeka, jazz nahradila estráda, ale až po roku 1948:

„Umelecký súbor Červenej armády usporiada v pondelok 28. mája o 18. hod. v Národnom divadle koncert piesni a tancov. Na programe sú spevy, tance, balety, akrobatika, sbory, jazz, ako aj úryvky z opery Nazar Stodola od Niščinského." ${ }^{11}$

Príspevok bol podporený grantom VEGA č. 1/0015/19.

\section{Bibliography}

\section{Sources}

časopisy a noviny Slovák, Gardista, Národné noviny z rokov 1938-1945.

Dokumenty 1939-1949, Ústav pamäti národa, 2004-2018 [online]. [Cit. 2018-6-20].

Dostupné z: https://www.upn.gov.sk/sk/dokumenty-1939-1945/.

CD Antológia slovenskej populárnej hudby vol. IV.-V, 1939-1945, HF 2008, SF 00572331.

\section{Selective literature}

BAKA, Igor. Politický systém a režim Slovenskej republiky v rokoch 1939-1940. Bratislava: Vojenský historický ústav, 2010.

BÁLINTOVÁ, LENKA. Džez, zakázaná hudba. Historická revue, 2000, roč. XI, č. 6, s. 29.

Čo Slovensko chcelo, to má; rozhovor s Pavlom Polanským. . týźdeñ [online]. 20. 9. 2008. [Cit. 20089-20]. Dostupné z: https://www.tyzden.sk/casopis/3286/co-slovensko-chcelo-to-ma.

GÁLOVÁ, Jana. Hudobné vysielanie slovenského rozhlasu v období 2. svetovej vojny. In Musicologica.eu [online]. 2012, 1. [Cit. 2012-05-12]. Dostupné z: http://www.musicologica.eu/?p=576.

HLAVATÝ, Jozef. Stažnost’ na lahkú hudbu (Téma s variáciami). Kultúra, XIV, č. 3, 1942, s. 116.

89 V nedelu dobročinný koncert. Pravda, č. 106, 29. 6. 1945, s. 2.

90 Pravda, č. 72, 19. 5. 1945, s. 3.

91 Koncert Červenej armády. Pravda, č. 77, 26. 5. 1945, s. 3. 
KOTEK, Josef. Kronika české synkopy 1903-1938, I. Půlstoleti českého jazzu a moderni populárni hudby v obrazech a svědectvi současnikũ. Praha: Supraphon, 1975.

KOTEK, Josef - HOŘEC, Jaromír. Kronika české synkopy 1939-1961, II. Půlstoleti českého jazzu a moderni populárni hudby v obrazech a svědectvi současniku. Praha: Supraphon, 1990.

KOURA, Petr. Swingaři a potápky v protektorátni noci. Protektorátni swingová subkultura a jeji svět. Praha: Academie, 2016.

MATZNER, Antonín - POLEDŇÁK, Ivan - WASSERBERGER, Igor a kol. Encyklopedie jazzu a moderni populárni hudby I. Praha: Supraphon, 1980, 2. vydanie, 1983, III. Československá scéna. Praha: Supraphon, 1990.

MAZZOLETTI, Adriano. Il jazz in Italia. Volume secondo dallo swing agli anni sessanta. Torino: EDT, 2010.

MAZZOLETTI, Adriano. Il jazz in Italia. Dalle origini alle grandi orchestre. Torino: EDT, 2004.

SCHINDLER, Agata. Maličká slzička. A Tiny teardrop. Bratislava: HC, 2016.

SCHVARC, Michal - HALLON, Ludovít - MIČKO, Peter. Pracovali v Tretej rǐsii. Bratislava: Veda, 2015.

ŠOLTÝS, Ladislav. Polstoročie slovenskej populárnej hudby. Hudobné križovatky IX. čast̉. Populár, 1983, roč. XV, č. 9, s. 23.

ZELENAY, Pavol - ŠOLTÝS, Ladislav. Hudba, tanec, pieseñ. Bratislava: HC, 2008.

Zpravodaj odborového sdruženi hudebniku pro Čechy a Moravu, december 1942, roč. XII, č. 12, s. 3. 